Tropical Journal of Pharmaceutical Research December 2016; 15 (12): 2745-2750

ISSN: 1596-5996 (print); 1596-9827 (electronic)

(1) Pharmacotherapy Group, Faculty of Pharmacy, University of Benin, Benin City, 300001 Nigeria.

All rights reserved.

Available online at http://www.tjpr.org

Original Research Article

http://dx.doi.org/10.4314/tjpr.v15i12.30

\title{
Screening for CYP2C19 Gene variants in a healthy Jordanian population
}

\author{
Salem Yasin ${ }^{1 *}$, Lubna Tahtamouni ${ }^{1}$, Rema Al-Khateeb ${ }^{1}$, Reem Abdellatif ${ }^{1}$, \\ Zainab Al-Mazaydeh', Ala'a Al-Emerieen ${ }^{2}$, Hakam Al-Khateeb ${ }^{3}$ and Al-Hakam \\ Al-Hadidi ${ }^{4}$ \\ ${ }^{1}$ Department of Biology and Biotechnology, Faculty of Science, The Hashemite University, ${ }^{2}$ Department of Medical Laboratory \\ Sciences, Faculty of Allied Medical Health, Zarqa Private University, Zarqa, ${ }^{3}$ Faculty of Medicine, Yarmouk University, \\ ${ }^{4}$ Department of Pharmacology, Faculty of Medicine, Jordan University of Science and Technology, Irbid, Jordan
}

*For correspondence: Email: salemmaloul@yahoo.com; Tel: +962797079332

Received: 1 June 2016

Revised accepted: 5 November 2016

\begin{abstract}
Purpose: To genotype healthy Jordanian population from three different provinces (Amman, Zarqa and Irbid) for cytochrome P4502C19 and to identify the allelic distribution of CYP2C19 variants in comparison with other findings around the world.

Methods: Healthy Jordanian volunteers were recruited from government hospitals. Two hundred and sixty volunteers were included in the study regardless of sex and age. CYP2C19*2, *3, *4, *5, and *6 alleles were studied using polymerase chain reaction-restriction fragment length polymorphism (PCR$R F L P$ ) technique.

Results: The results show that the Jordanian population tested exhibited 9 genotypes out of the 21 expected CYP2C19 genotypes. CYP2C19*1/*1 and ${ }^{*} 2 /{ }^{*} 2$ genotypes were the most prominent in the sample population, while CYP2C19*2/ ${ }^{*} 5$ was the least prevalent genotype. The frequencies of the CYP2C19 variants did not deviate from Hardy-Weinberg equilibrium. Allele frequency of CYP2C19*2 in the Jordanian population was statistically different from that found in most Europeans, North and South Americans, Africans, and some Asian ethnic communities but not with South-East Asian populations (China, Chinese-Taiwanese, and Philippines) and Australian Aborigines.

Conclusion: The findings of this study confirm the importance of CYP2C19 genotyping prior to drug therapy administration to achieve optimal dosage and cost-effective therapy.
\end{abstract}

Keywords: Cytochrome P450, RFLP-PCR, Allele frequency, Pharmacogenetics, Optimal dosage, Costeffective therapy

Tropical Journal of Pharmaceutical Research is indexed by Science Citation Index (SciSearch), Scopus, International Pharmaceutical Abstract, Chemical Abstracts, Embase, Index Copernicus, EBSCO, African Index Medicus, JournalSeek, Journal Citation Reports/Science Edition, Directory of Open Access Journals (DOAJ), African Journal Online, Bioline International, Open-J-Gate and Pharmacy Abstracts

\section{INTRODUCTION}

Individual variation in response to drugs is a substantial clinical problem that can be inherited. The genetically determined variability in drug response defines the research area known as pharmacogenetics [1].
One of the main directions in development of pharmacogenetics is identifying genes and allelic variants of genes that affect human's response to drugs [2]. Polymorphisms of genes encoding drug metabolism enzymes, drug transporters, and drug receptors, which are involved in drug responses, have been reported [3,4]. Genetic variation can account for as much as $95 \%$ of variability in drug disposition and effect [5]. As 
the main cause of the variation in drug response, attention has focused on genetic polymorphisms. Single nucleotide polymorphism (SNP) of DNA produces variation in drug response and has become a representative research target in pharmacogenetics [6].

It is known that many polymorphisms that influence drug response and which probably contribute significantly to phenotypic variation in drug response have significant allele frequency differences among racial or ethnic groups $[3,7,8]$.

Of all genetic factor that affect drug treatment, those affecting the activity of the drug metabolizing enzyme cytochrome P450 are currently considered the quantitatively most important [6]. Humans have been estimated to have at least 57 different CYP genes, but the major drug metabolizing human $\mathrm{P} 450$ genes are CYP1A, CYP2B, CYP2C, CYP2D, CYP2E and CYP3A $[9,10]$. The CYP2C19 gene is located within a cluster of CYP genes on the 4th band of region 2 of the long arm of chromosome 10 (10q24) [11].

CYP2C19 exhibits high genetic polymorphism, including common defective variants. Singlebase substitutions in the coding sequence lead to a splicing defect and premature stop codon, and therefore to null function of the enzyme. These variants together (CYP2C19*2 and CYP2C19*3) are responsible for the majority of the CYP2C19related poor metabolism (PM) phenotypes in different populations [12].

Pharmacogenetics is a rapidly evolving field and a lot of information regarding genetic polymorphism is being generated for many ethnic groups, particularly Caucasians and Orientals. However, data on Arab populations is still sparse. There is a need to fill the gaps in pharmacogenetics knowledge pertaining to the Jordanian population. Thus, the aim of this study was to genotype healthy Jordanian people for cytochrome $\mathrm{P} 4502 \mathrm{C} 19$, to identify the variant alleles of CYP2C19 and to compare the results with findings in other countries.

\section{METHODS}

\section{Study group}

Healthy Jordanian volunteers were randomly recruited from governmental hospitals of three provinces (Amman, Zarqa and Irbid). Two hundred and sixty volunteers were included in the study regardless of sex and age. All volunteers gave their written, informed consent. The study was approved by the Institutional Review Board (IRB) [AM/16/13/10/1200085] of the Hashemite University, Zarqa, Jordan which conforms to the World Medical Association Declaration of Helsinki [13].

\section{CYP2C19 genotyping}

Three milliliters of peripheral blood were withdrawn on ethylenediaminetetraacetic acid EDTA tube from each participant by venous puncture. DNA was extracted from $300 \mu \mathrm{L}$ blood using a commercially available kit (Wizard Genomic DNA Purification Kit, Promega, Madison, USA). The CYP2C19*2, * $3,{ }^{*} 4$, ${ }^{*} 5$, and *6 alleles were studied using the PCR-RFLP technique. The PCR reactions were carried out in a BioRad thermocycler (Mycycler, BioRad, USA). All PCR primers are indicated from $5^{\prime}$ to $3^{\prime}$ end and are provided in Table 1. The primers sequences were based on published literature [14-17].

The amplification products were then digested overnight with the appropriate restriction endonuclease (Table 1). The digested PCR products were resolved by electrophoresis in $3 \%$ agarose gels stained with ethidium bromide. The result of the electrophoresis was detected and documented using the CSL-MicroDoc and Canon digital camera (Cleaver-Scientific, UK).

\section{Statistical analysis}

The observed genotypes and allele frequencies were compared with those expected, in order to verify the Hardy-Weinberg equilibrium. Allelic frequencies and prevalence were compared between Jordanians and other populations using the test for differences between proportions. The statistical analysis has been performed using STATISITCA 7 analysis program (StatSoft Inc., Ok, USA). A value of $p<0.05$ was considered statistically significant.

\section{RESULTS}

\section{Population characteristics}

The total number of subjects enrolled in the current study was 260 . One hundred and fifty nine of them were females $(61.2 \%)$ and the other $101(38.8 \%)$ were males. The age of the subjects ranged from 18 to 59 years with a mean of 24.1 years. There was no significant difference (data not shown) between the mean age of females (24.3 years) and males (23.7 years) ( $p>$ 0.05). 
Table 1: CYP2C19 variants, PCR primers, PCR amplicons and their respective restriction digestion products

\begin{tabular}{|c|c|c|c|}
\hline $\begin{array}{l}\text { CYP2C19 } \\
\text { variant }\end{array}$ & Nucleotide sequence & $\begin{array}{l}\text { PCR amplicon } \\
\text { size (bp) }\end{array}$ & $\begin{array}{l}\text { Restriction enzyme/ } \\
\text { fragment size }\end{array}$ \\
\hline *2 & $\begin{array}{l}\text { F: AATTACAACCAGAGCTTGGC } \\
\text { R:TATCACTTTCCATAAAAGCAAG }\end{array}$ & 168 & $\begin{array}{l}\text { Smal/ } \\
118 b p+50 b p\end{array}$ \\
\hline *3 & $\begin{array}{l}\text { F: AAATTGTTTCCAATCATTTAGCT } \\
\text { R: ACTTCAGGGCTTGGTCAATA }\end{array}$ & 271 & $\begin{array}{l}\text { BamHl/ } \\
175 \mathrm{bp}+96 \mathrm{pb}\end{array}$ \\
\hline *4 & $\begin{array}{l}\text { F: ATTATATTAACAAGAGGAGAAGGCTGCA } \\
\text { R: TTGGTTAAGGATTTGCTGACA }\end{array}$ & 195 & $\begin{array}{l}\text { Pstl/ } \\
167 b p+28 b p\end{array}$ \\
\hline *5 & $\begin{array}{l}\text { F: TCCCTATGTTTGTTATTTCCAGG } \\
\text { R: GAGCAGCCAGACCATCTGTG }\end{array}$ & 229 & $\begin{array}{l}\text { BstX/ } \\
203 b p+26 b p\end{array}$ \\
\hline *6 & $\begin{array}{l}\text { F: ATACAATGTAAATATGAATCTAAG } \\
\text { R: CAGGACTCCAAATAAAAGATC }\end{array}$ & 675 & $\begin{array}{l}\text { BsmB I/ } \\
490 \mathrm{bp}+185 \mathrm{bp} \\
\text { or } \\
\text { Pstl/ } \\
483 \mathrm{bp}+192 \mathrm{bp}\end{array}$ \\
\hline
\end{tabular}

${ }^{\star}$ Represents an allelic variant

\section{CYP2C19 genotyping results}

DNA extraction, PCR amplification and restricted PCR products were performed and recorded for all samples. Restriction products of the genomic DNA for the CYP2C19 variants ( ${ }^{*} 2,{ }^{*} 3,{ }^{*} 4,{ }^{*} 5$ and $\left.{ }^{*} 6\right)$ and their respective restriction enzymes were as shown in Table 1.

\section{Genotype characteristics}

The size of PCR amplicons and restriction digestion products were similar to what have been previously reported (Table 1 and Figure1). Genotypic and allelic frequencies for the six CYP2C19 variants were determined according to the count method (Table 2).

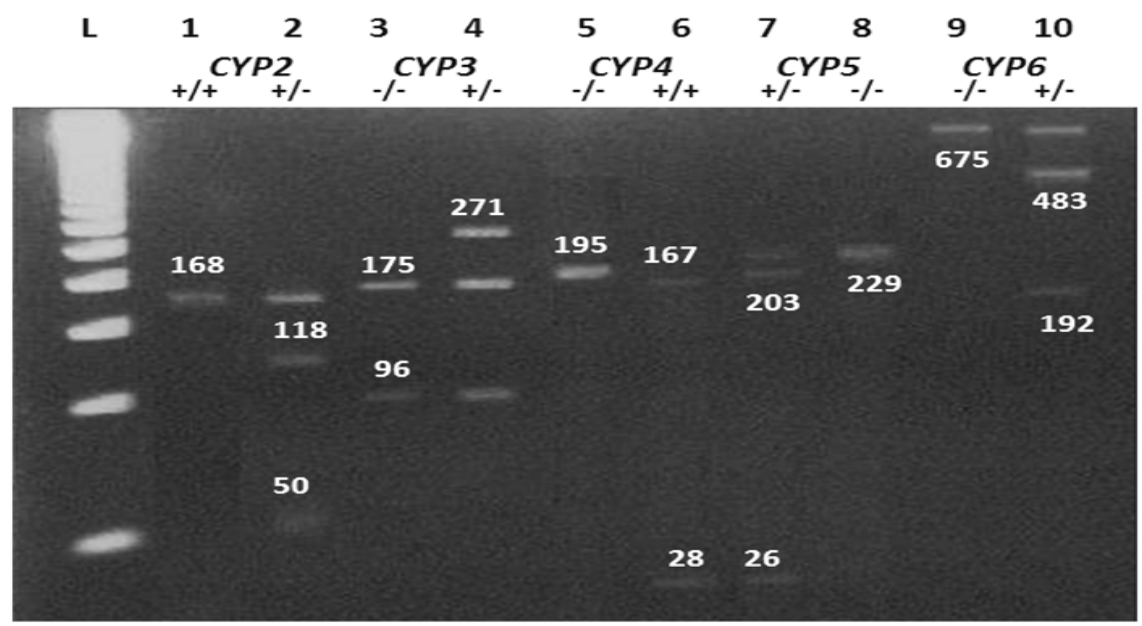

Figure 1: Representative gel electrophoresis showing the analysis of CYP2C19 variants. Lane L: 50bp DNA molecule marker, lane 1: CYP2C19*2 homozygote; lane 2: CYP2C19*2 heterozygote; lane 3: CYP2C19*3 wild type ${ }^{\text {; }}$; lane 4: CYP2C19*3 heterozygote; lane 5: CYP2C19*4 wild type, lane 6: CYP2C19*4 homozygote; lane 7: CYP2C19*5 heterozygote, lane 8: CYP2C19*5 wild type; lane 9: CYP2C19*6 wild type; lane 10: $C Y P 2 C 19^{\star} 6$ heterozygote. ${ }^{a}$ : Wild type: CYP2C191***1; ${ }^{*}$ represents an allelic variant

Table 2: CYP2C19 genotypic and allelic frequencies in the Jordanian population

\begin{tabular}{|c|c|c|c|c|c|c|c|c|c|}
\hline $\begin{array}{l}\text { CYP2C19 } \\
\text { Genotype }\end{array}$ & ${ }^{*} 1 /{ }^{*} 1$ & ${ }^{*} 1 /{ }^{*} 2$ & ${ }^{*} 1 /{ }^{*} 6$ & ${ }^{*} 2 /{ }^{*} 2$ & ${ }^{*} 2 /{ }^{*} 3$ & ${ }^{*} 2 /{ }^{*} 4$ & ${ }^{*} 2 /{ }^{*} 5$ & ${ }^{*} 2 /{ }^{*} 6$ & ${ }^{*} 4 /{ }^{*} 4$ \\
\hline Frequency & 0.5731 & 0.0077 & 0.0269 & 0.3038 & 0.0154 & 0.0154 & 0.0038 & 0.0231 & 0.0308 \\
\hline $\begin{array}{l}\text { CYP2C19 } \\
\text { Allele }\end{array}$ & ${ }^{*} 1$ & ${ }^{*} 2$ & *3 & *4 & ${ }^{*} 5$ & ${ }^{*} 6$ & & & \\
\hline Frequency & 0.5904 & 0.3365 & 0.0077 & 0.0385 & 0.0019 & 0.0250 & & & \\
\hline
\end{tabular}


This study has demonstrated a wide presence of CYP2C19*1 allele in 158 unrelated healthy Jordanian individuals of which 149 (94.30\%) were CYP2C $19^{*} 1 /{ }^{*} 1$ homozygotes, $2(1.27 \%)$ were CYP2C19*1/*2 heterozygotes and $7(4.43$ $\%$ ) were $C Y P 2 C 19^{*} 1{ }^{*} 6$ heterozygotes. On the other hand, CYP2C19*2 allele was reported in 96 healthy unrelated Jordanian individuals, of which $79(82.29 \%)$ were CYP2C19*2/*2 homozygotes, $2(2.08 \%)$ were $C Y P 2 C 19^{*} 1{ }^{*} 2$ heterozygotes, 4 $(4.17 \%)$ were CYP2C19*2/*3 compound heterozygotes, $4(4.17 \%)$ were CYP2C19*2/ 4 compound heterozygotes, 1 (1.04\%) was CYP2C19*2/*5 compound heterozygote, and 6 $(6.25 \%)$ were $C Y P 2 C 19^{*} 2 /{ }^{*} 6$ compound heterozygotes, Furthermore, the study has shown the presence of CYP2C19* $4 /{ }^{*} 4$ homozygosity in $8(3.08 \%)$ individuals. Therefore, 104 (40\%) individuals - 96 CYP2C19*2 allele homozygotes and heterozygotes $(92.31 \%)$ and 8 (7.69 \%) CYP2C19*4 allele homozygotes - are predicted to be poor metabolizers.

In addition, Table 2 shows that the Jordanian population tested exhibited nine genotypes out of the 21 expected CYP2C19 genotypes. CYP2C19*1/*1 and ${ }^{*} 2 /{ }^{*} 2$ genotypes were the most prominent genotypes in the Jordanian sample population with a frequency of 0.5731 and 0.3038 , respectively. CYP2C $19^{*} 2 /{ }^{*} 5$ was the least prevalent genotype with a frequency of 0.0038. Furthermore, Table 2 shows the allelic frequencies of the six CYP2C19 variants. CYP2C 19*1 and *2 were the most dominant variants with allelic frequencies of 0.5904 and 0.3365 , respectively. CYP2C19*5 was the least dominant variant with an allelic frequency of 0.0019. The frequencies of the CYP2C19 variants in the Jordanian population were found not to deviate from the Hardy-Weinberg equilibrium.

Comparison between Jordanian allelic frequencies of CYP2C19*2 and ${ }^{*} 3$ alleles and that of other ethnic populations worldwide is shown in Table $3[18,19]$. Allele frequency of CYP2C19*2 in the Jordanian population was statistically different $(p<0.05)$ from that found in most of the European, North and South Americans, Africans, and some Asian ethnic communities. No significant differences regarding the CYP2C19*2 allele frequency were found when comparing Jordanians to South-East Asian populations (China, Chinese-Taiwanese, and Philippines) and Australian Aborigines. In the case of $C Y P 2 C 19 * 3$ allele, a lower distribution as in Jordanians have been found in European, North and South America, Africa, and some South-East Asian ethnic groups. Compared to the Jordanian population, a significantly higher allelic frequency of CYP2C19*3 allele was found in East-South Asian ethnic groups (China, Chinese-Taiwanese, Philippines, Japan and Korea), Australian Aborigines and Oceanians ( $p$ $<0.05$ ). In this study, no statistical analysis was carried out for CYP2C19*4, *5, and *6 variants due to the absence of data for most of the populations tested $[18,19]$.

\section{DISCUSSION}

Various studies indicated the genetic basis for interethnic and inter-individual variability in the metabolism of CYP2C19 substrates [20,21]. This leads to dividing individuals according to their CYP2C19 genotype and the associated CYP2C19 enzyme activity into four categories: Extensive, Intermediate, Poor and Ultrarapid metabolizers, according to individuals' response to drug therapy [6].

The distribution of CYP2C19*2 allele in the Jordanian population is consistent with the relatively high frequency of CYP2C19*2 allele worldwide [22], suggesting that CYP2C19*2 was present in humans way before the separation of humans into different distinctive populations [23]. However, the higher frequency of such variant in the Jordanian population compared to some regional countries such as Saudi Arabia, Egypt, Gaza Strip (Palestine), and Turkey [19] may be hypothesized to be the result of emigration and admixture between the native Jordanians and different populations such as the Circassians, Palestinians, Syrian, Iraqi, Lebanese, Egyptians and other ethnic Arab populations. On the other hand, the distribution of CYP2C $19^{*} 3$ allele in the Jordanian population was found to be similar to its distribution within the international populations except the south-East Asians, Australian Aborigines and Oceanians [19], suggesting that this allele may be specific to these populations and that it occurred quite recently, after the separation of Caucasian and Oriental groups $[23,24]$.

\section{Limitations of the study}

One major limitation of the current study is the scarce of information regarding CYP2C19 allele frequencies in Arab populations in order to make any kind of comparison. In addition, allele frequencies of CYP2C19*4, *5 and *6 in other populations are also lacking which made it impossible to draw any conclusion regarding these genotypes. 
Table 3: Comparative CYP2C19*2 and *3 allele frequencies in various population

\begin{tabular}{|c|c|c|c|c|c|}
\hline Population & Sample size & $\begin{array}{l}C Y P 2 C 19 * 2 f \\
\text { Frequency }\end{array}$ & $P$-value & $\begin{array}{l}C Y P 2 C 19 * 3 f \\
\text { Frequency }\end{array}$ & $P$-value \\
\hline $\begin{array}{l}\text { Jordan } \\
\text { Europe }\end{array}$ & \multicolumn{4}{|c|}{ Europe } & - \\
\hline Faroe Islands & 310 & 0.188 & 0.00001 & 0.0000 & 0.1406 \\
\hline Denmark & 239 & 0.16 & 0.00001 & 0.0000 & 0.1747 \\
\hline Germany & 328 & 0.159 & 0.00001 & 0.0020 & 0.1947 \\
\hline Croatia & 200 & 0.15 & 0.00001 & 0.0000 & 0.1588 \\
\hline Sweden & 83 & 0.14 & 0.00001 & 0.0010 & 0.4183 \\
\hline Russia & 290 & 0.114 & 0.00001 & 0.0030 & 0.3011 \\
\hline Italy & 360 & 0.111 & 0.00001 & 0.0000 & 0.0577 \\
\hline French Caucasians & 172 & 0.0013 & 0.00001 & 0.00003 & 0.1908 \\
\hline Romania & 200 & 0.137 & 0.00001 & 0.0000 & 0.1588 \\
\hline Belgium & 121 & 0.091 & 0.00001 & 0.0000 & 0.2704 \\
\hline Portugal & 153 & 0.13 & 0.00001 & 0.0000 & 0.2154 \\
\hline \multicolumn{6}{|l|}{ North America } \\
\hline European American & 87 & 0.13 & 0.00001 & 0.0000 & 0.3498 \\
\hline African American & 75 & 0.25 & 0.0033 & 0.0000 & 0.3858 \\
\hline Canadian Inuit & 89 & 0.11 & 0.00001 & 0.0000 & 0.3443 \\
\hline Canadian Native Indian & 115 & 0.191 & 0.00001 & 0.0000 & 0.2826 \\
\hline \multicolumn{6}{|l|}{ South America } \\
\hline Colombia & 189 & 0.087 & 0.00001 & 0.0000 & 0.1687 \\
\hline Bolivia & 778 & 0.078 & 0.00001 & 0.0010 & 0.0276 \\
\hline \multicolumn{6}{|l|}{ Africa } \\
\hline Tanzania & 251 & 0.18 & 0.00001 & 0.0100 & $>0.999$ \\
\hline Ethiopia & 114 & 0.14 & 0.00001 & 0.0300 & 0.1580 \\
\hline Benin & 111 & 0.13 & 0.00001 & 0.0000 & 0.2911 \\
\hline Egypt & 247 & 0.109 & 0.00001 & 0.0020 & 0.2482 \\
\hline Zimbabwean & 87 & 0.13 & 0.00001 & 0.0000 & 0.4123 \\
\hline Venda & 78 & 0.22 & 0.0005 & 0.0000 & 0.3759 \\
\hline \multicolumn{6}{|l|}{ Asia } \\
\hline Saudi Arabia & 97 & 0.15 & 0.00001 & 0.0000 & 0.3236 \\
\hline Palestine (Gaza Strip) & 200 & 0.0577 & 0.00001 & 0.0288 & 0.1352 \\
\hline Jewish Israel & 140 & 0.15 & 0.00001 & 0.0100 & 0.2359 \\
\hline Iran & 200 & 0.14 & 0.00001 & 0.0000 & 0.1568 \\
\hline Turkey & 404 & 0.12 & 0.00001 & 0.0040 & 0.3424 \\
\hline China & 121 & 0.455 & 0.784 & 0.0450 & 0.0276 \\
\hline Chinese-Taiwanese & 63 & 0.32 & 0.084 & 0.0500 & 0.032 \\
\hline Philippines & 52 & 0.39 & 0.5069 & 0.0800 & 0.0017 \\
\hline North India & 121 & 0.297 & 0.0092 & 0.0000 & 0.2704 \\
\hline Japan & 217 & 0.274 & 0.0002 & 0.1080 & 0.00001 \\
\hline Korea & 103 & 0.209 & 0.00001 & 0.1170 & 0.00001 \\
\hline \multicolumn{6}{|l|}{ Australia and Oceania } \\
\hline Australian Aborigines & 227 & 0.355 & 0.0568 & 0.1430 & 0.00001 \\
\hline $\begin{array}{l}\text { Vanuatu + other pacific } \\
\text { ocean islands }\end{array}$ & 5538 & 0.633 & 0.00001 & 0.1440 & 0.00001 \\
\hline
\end{tabular}

${ }^{*}$ Represents an allelic variant

\section{CONCLUSION}

Earlier studies indicate that CYP2C19 polymorphic nature plays a crucial role in the pharmacokinetics of drug therapy, thus suggesting the importance of CYP2C19 genotyping prior to drug administration to achieve optimal dosage adjustment and costeffective therapy. The findings of this study confirm the importance of CYP2C19 genotyping prior to drug therapy administration to achieve optimal dosage and cost-effective therapy.

\section{DECLARATIONS}

\section{Acknowledgement}

This study was supported by the Deanship of Scientific Research and Graduate Studies, The Hashemite University, Zarqa, Jordan. The authors thank Professor Ali Elkarmi for help with statistical analysis.

\section{Conflict of Interest}

No conflict of interest associated with this work. 


\section{Contribution of Authors}

The authors declare that this work was done by the authors named in this article and all liabilities pertaining to claims relating to the content of this article will be borne by them.

\section{Open Access}

This is an Open Access article that uses a funding model which does not charge readers or their institutions for access and distributed under the terms of the Creative Commons Attribution License (http://creativecommons.org/licenses/by 14.0) and the Budapest Open Access Initiative (http://www.budapestopenaccessinitiative.org/rea d), which permit unrestricted use, distribution, and reproduction in any medium, provided the original work is properly credited.

\section{REFERENCES}

1. Motulsky AG. Drug reactions, enzymes and biochemical genetics. J Am Med Assoc 1957; 165: 835-837.

2. Wolf $C R$, Smith G, Smith RL. Science, medicine and the future: Pharmacogenetics. BMJ 2000; 320: 987-990.

3. Evans WE, Relling MV. Pharmacogenomics: Translating functional genomics into rational therapeutics. Science 1999; 286: 487-491.

4. Goldstein DB, Tate SK, Sisodiya SM. Pharmacogenetics goes genomic. Nat Rev Genet 2003; 4: 937-947.

5. Kalow W, Tang BK, Endrenyi L. Hypothesis: Comparisons of inter- and intra-individual variations can substitute for twin studies in drug research. Pharmacogenetics 1998; 8: 283-289.

6. Sim SC, Risinger C, Dahl ML, Aklillu E, Christensen M, Bertilsson L, Ingelman-Sundberg M. A common novel CYP2C19 gene variant causes ultrarapid drug metabolism relevant for the drug response to proton pump inhibitors and antidepressants. Clin Pharmacol Therapeutics 2006; 79: 103-113.

7. Tate SK, Goldstein DB. Will tomorrow's medicines work for everyone? Nat Genet 2004; 36:34-42.

8. Engen RM, Marsh S, van Booven DJ, Mcleod HL. Ethnic differences in pharmacogenetically relevant genes. Curr Drug Targets 2006; 7: 1641-1648.

9. McGinnity DF, Parker AJ, Soars M, Riley RJ. Automated definition of the enzymology of drug oxidation by the major human drug metabolizing cytochrome P450s. Drug Metabol Dispos 2000; 28: 1327-1334.

10. Guengerich FP. Cytochrome P450s and other enzymes in drug metabolism and toxicity. AAPS J 2006; 8: E101E111.

11. Meehan RR, Gosden JR, Rout D, Hastie ND, Friedberg $T$, Adesnik M, Buckland R, van Heyningen V, Fletcher J, Spurr NK, et al. Human cytochrome P-450 PB-1: A multigene family involved in mephenytoin and steroid oxidations that maps to chromosome 10. Am J Hum Genet 1988; 42: 26-37.

12. Xie HG, Kim RB, Wood AJJ, Stein CM. Molecular basis of ethnic differences in drug disposition and response. Ann Rev Pharmacol Toxicol 2001; 41: 815-850.

13. World Medical Association. Declaration of Helsinki: Ethical Principles for Medical Research Involving Human Subjects. JAMA 2013; 310(20): 2191-2194.

14. Xiao ZS, Goldstein JA, Xie HG, Blaisdell J, Wang W, Jiang $\mathrm{CH}$, Yan $\mathrm{FX}$, He N, Huang $S L, X u Z H$, et al. Differences in the incidence of the CYP2C19 polymorphism affecting the S-mephenytoin phenotype in Chinese Han and Bai populations and identification of a new rare CYP2C19 mutant allele. J Pharmacol Exp Ther 1997; 281: 604-609.

15. Ferguson RJ, De Morais SM, Benhamou S, Bouchardy C, Blaisdell J, Ibeanu G, Wilkinson GR, Sarich TC, Wright JM, Dayer $P$, et al. A new genetic defect in human CYP2C19: Mutation of the initiation codon is responsible for poor metabolism of S-mephenytoin. $J$ Pharmacol Exp Ther 1998; 284: 356-361.

16. Ibeanu GC, Blaisdell J, Ghanayem BI, Beyeler C, Benhamou S, Bouchardy C, Wilkinson GR, Dayer P, Daly AK, Goldstein JA. An additional defective allele, CYP2C $19 * 5$, contributes to the S-mephenytoin poor metabolizer phenotype in Caucasians. Pharmacogenetics 1998; 8: 129-136.

17. Tamminga $W$, Wemer J, Oosterhuis $B$, de Zeeuw $R$, de Leij L, Jonkman J. The prevalence of CYP2D6 and CYP2C19 genotypes in a population of healthy Dutch volunteers. Eur J Clin Pharmacol 2001; 57: 717-722.

18. Buzoianu AD, Trifa AP, Popp RA, Militaru MS, Militaru CF, Bocsan Cl, Farcas MF, Pop IV. Screening for CYP2C19*2, *3 and *4 gene variants in a Romanian population study group. Farmacia 2010; 58(6): 806-817.

19. Abu-Eid IS, Gharbieh AM, Abed AA, Sharif AF. CYP2C19 genotypes in a population of healthy volunteers and in children with haematological malignancies in Gaza strip. Can J Clin Pharmacol 2009; 16: e156-e162.

20. Desta Z, Zhao X, Shin JG, Flockhart DA. Clinical significance of the cytochrome P450 2C19 genetic polymorphism. Clin Pharmacokinet 2002; 41: 913-958.

21. Ingelman-Sundberg $M$. Genetic polymorphisms of cytochrome P450 2D6 (CYP2D6): Clinical consequences, evolutionary aspects and functional diversity. Pharmacogenom J 2005; 5: 6-13.

22. Gonzalez FJ. Molecular genetics of the $P-450$ superfamily. Pharmacol Ther 1990; 45: 1-38.

23. Ruas JL, Lechner MC. Allele frequency of CYP2C19 in a Portuguese population. Pharmacogenetics 1997; 7: 333335.

24. Scordo MG, Caputi AP, D'Arrigo C, Fava G, Spina E. Allele and genotype frequencies of CYP2C9, CYP2C19 and CYP2D6 in an Italian population. Pharmacol Res 2004; 50: 195-200 